\title{
Motif Tenun Sebagai Bentuk Bahasa Rupa Dari Masyarakat Suku Mbojo di Bima Nusa Tenggara Barat
}

\author{
Erri Fajarriny ${ }^{1}$, Yan Yan Sunarya ${ }^{2}$ \\ ${ }^{1,2}$ Magister Desain, Fakultas Seni Rupa dan Desain, \\ Institut Teknologi Bandung, Bandung, Indonesia
}

\begin{abstract}
One of the characteristics of Bima City lies in its handicrafts, namely woven fabrics made by the Mbojo Tribe for generations. The motifs that are often used are motifs with images of flowers, leaves, or lines. Each motif has its meaning and is a form of message used by the people of the Bima kingdom before they knew writing. Over time, the meaning of inherited motifs has shifted. The shift is marked by modern weavers who do not know the meaning. With this phenomenon, the knowledge passed down by previous generations will stop at the current weaver's so that the cultural values contained are non-existent and even difficult to translate. The primary study analyzes the Bima weaving motif by exploring the four main motifs to find their meaning. The research was conducted using a qualitative method. In this method, data collection was supported by a literature study, then field observations and interviews to determine the overall motive to comply with applicable regulations. The qualitative approach is followed by a more profound analysis using the theory of visual language forms. The purpose of this study is to provide a reference to the weavers of the Mbojo Tribe to find out the meaning of the motifs contained in the Bima weaving to preserve the Bima culture.
\end{abstract}

\section{Keywords}

Motif, Mbojo Tribe, Visual Language, Woven Fabric 


\title{
Motif Tenun Sebagai Bentuk Bahasa Rupa Dari Masyarakat Suku Mbojo di Bima Nusa Tenggara Barat
}

\author{
Erri Fajarriny \&Yan Yan Sunarya
}

\section{PENDAHULUAN}

Nusa Tenggara Barat merupakan salah satu provinsi yang ada di Indonesia yang memiliki ibu kota bernama Mataram, dan memiliki kota-kota yang dihuni oleh suku yang berbeda-beda tiap daerah, salah satunya Kota Bima. Sebelum menjadi sebuah kota, Bima merupakan sebuah kota yang dipimpin oleh masa kesultanan Bima pada saat itu. Bima merupakan salah satu kota yang berlokasi pada ujung timur pulau Nusa Tenggara Barat berdekatan dengan provinsi yang berada di sebelahnya, yakni Nusa Tenggara Timur. Kota Bima merupakan sebuah tempat yang memiliki potensi budaya yang sedang berkembang. Berkembang dalam artian memiliki potensi, namun terdapat beberapa kendala dalam upaya mengenalkan Bima itu sendiri selain lewat media sosial. Kota Bima ini sebagian besarnya dihuni oleh suku aslinya yakni suku Mbojo dan juga etnis lainnya. Suku ini memiliki kebiasaan menenun kain sejak zaman dahulu secara turun temurun, kain tersebut dinamai dengan kain Mbojo atau kainnya orang Bima [1]. Selain menjadi salah satu komoditi, kain tenun tersebut menjadi salah satu runutan sejarah dari peradaban kerajaan atau kesultanan Bima pada waktu itu. Kota Bima ini sendiri memiliki latar belakang sejarah dan leluhur yang mempunyai nilai eksotis, salah satunya yakni kain tenun khas Bima ini.

Sejak zaman kerajaan, para remaja yang ada pada masa itu diwajibkan untuk bisa menenun yang di mana kain tersebut akan digunakan sebagai pakaian sehari-hari pada masa kesultanan Bima sebagai hijab atau penutup badan. Selain itu pula, keterampilan menenun atau Muna Ro Medi menjadi suatu syarat untuk perempuan bisa menikah. Keterampilan menenun tersebut nantinya akan digunakan sebagai salah satu mata pencaharian [2]. Selain dijadikan pakaian sehari-hari, seperti yang sudah disebut di atas kain tenun ini menjadi salah satu sektor perekonomian dari masyarakat setempat. Selain bercocok tanam, berladang, bertani dan beternak masyarakat suku Mbojo ini menggunakan hasil tenunan tersebut. Dari hasil tenun tersebut beberapa penenun yang berada di daerah Rabadompu pun menjelaskan, bahwa dirinya menghasilkan kain tenun tersebut bertujuan untuk membiayai sekolah ataupun kebutuhan sehari-hari. Maka dari itu kain tenun ini sangat wajib bagi wanita-wanita muda ataupun dewasa untuk membuatnya.

Kain Mbojo menggunakan perpaduan dari tiga warna, yang ditenun secara zigzag dengan motifmotif yang berbeda. Motif yang di gunakan beragam namun hanya terdiri dari dua unsur yakni flora atau alam sekitarnya kecuali manusia dan hewan. Pasalnya pada masa kesultanan Bima (1640-1950) sudah menganut ajaran Islam yang di mana pada masa itu dilarang menggunakan gambar manusia dan hewan sebagai motif [3]. Karena dipercaya hal tersebut dapat membawa ajaran lama, di mana manusia dan hewan memiliki kekuatan gaib yang harus disembah. Jenis makna simbol tenun khas Bimapun beragam mulai dari tenun Songket, Salungka, Masrai, Nggoli, Pa'a, Bali dan jenis lainnya. Jenis tersebut juga mempengaruhi keragaman motif yang tercipta mulai dari motif bunga, daun, garis-garis ataupun kotak-kotak. Pada zaman dahulu, motif-motif ini sering dikaitkan dengan aspek keagamaan, upacara adat dalam ritual kelahiran, kematian dan perkawinan. Tiap kain dan motif memiliki kaitannya dengan nilai-nilai dan unsur-unsur kebudayaan pada tiap daerahnya yang menunjukkan atau sebagai bentuk ekspresi pengakuan terhadap keberadaan, keagungan dan kebesaran Tuhan Sang Maha Pencipta kehidupan semua makhluk di dunia. Sehingga pada sehelai kain tersirat makna yang sangat dalam tentang arti kehidupan. Selain itu, warna dan jenis bahan kain tenun ini di gunakan oleh lapisan masyarakat tertentu. Motif-motif kain tenun yang ada di Kota Bima tidaklah banyak seperti motif kain tenun daerah lainnya

Berdasarkan ketentuannya, motif-motif kain tenun yakni Bunga samobo, Bunga Satako (Bunga Setangkai), Bunga Aruna, Bunga Kakando, Motif Garis, Motif Geometris, Nggusu Tolu, Nggusu Upa, 
Pado Waji, Nggusu Waru. Motif motif tersebut mempunyai makna yang berkaitan dengan kepercayaan kepada Allah dan kehidupan sehari-hari atau alam sekitarnya. Kebanyakan dari motif-motif tersebut menggambarkan pola tiga dari suku Bima, yang di mana tingkatan pertama yakni hubungan kepada Tuhan, tingkatan kedua hubungan antar manusia dan yang tingkatana paling bawah hubungan antar hewan atau makhluk yang kedudukannya dibawah manusia. Berhubungan pula dengan pola bangunannya, yang memiliki tiga pola antara dunia atas, tengah dan bawah. Motif yang terkandung dalam kain tenun Mbojo ini merupakan ornamen atau motif yang diduga memiliki arti tertentu. Arti tersebut bisa sebuah bentuk rupa dari masyarakat Mbojo sebelum mengenal tulisan ataupun pesan moral dari kehidupan bermasyarakat seperti apa. Walaupun pada masa kerajaan masyarakat sudah mengenal aksara, namun masyarakat pada zaman dahulu lebih gemar menenun dan mengekspresikan pesan tersebut melalui tenun yang akan digunakannya baik untuk sehari-hari maupun dalam upacara adat [4].

Bahasa rupa merupakan sebuah bentuk yang merangkul semua karya yang secara langsung bias dipegang, dilihat dan dirasakan. Juga sebagai perantara antar seniman atau pengrajin tenun itu sendiri dengan masyarakat yang melihatnya. Dalam buku Bahasa Rupa yang ditulis oleh Prof. Primadi, Bahasa rupa itu sendiri terbagi menjadi dua. Pertama Bahasa rupa modern yang di mana sistem penggambarannya disebut dengan NPM (Natural Perspective Moemnopname) kemudian yang kedua yakni RWD (Ruang Waktu Datar) [5]. Dalam kasus motif tenun ini, yang sering digunakan yakni sistem penggambaran RWD, yang di mana setiap suku di Indonesia memiliki cara penggambaran yang berbedabeda sejak zaman dahulu sebelum mengenal tulisan. Melalui gambar atau visual yang direalisasikan seperti contohnya lukisan dinding yang ada di gua-gua ataupun relief candi yang berisi cerita atau makna yang tersembunyi. Sama halnya pada motif tenun yang sudah diterapkan pada masa kerajaan zaman dahulu, beberapa kain tenun tersebut memiliki cerita ataupun makna yang religius dan sangat berkaitan dengan Tuhan dan alam sekitar.

Namun, seiring perkembangannya waktu, kain tenun Bima ini semakin lama mengalami pergeseran makna. Menurut hasil observasi dan kunjungan yang dilakukan oleh peneliti, masih banyak penenun yang menenun tanpa mengetahui makna apa yang terkandung dalam kain tersebut. Dalam pembahasan ini, para pengrajin tenun ini, selain menenun dengan motif yang sudah ditentukan, semakin banyak para pengrajin yang menenun dengan motif atau budaya luar ataupun menggabungkan motif yang berbeda suku dan ketentuan tanpa mengacu dengan nilai dan norma, namun hal tersebut diperbolehkan apabila tidak bertentangan dengan nilai-nilai dan norma-norma budayanya. Hal ini dikarenakan penenun-penenun tersebut mengikuti bagaimana permintaan pasar pada saat itu. Sedangkan motif tenun tersebut dibuat berdasarkan ketentuan dan norma terhadap Tuhan, adapun yang dibuat untuk mengadakan ritual adat ataupun upacara tertentu. Dari masalah tersebut para penenun banyak yang tidak mengetahui dan tidak menurunkan pengetahuan makna atau filosofi yang terkandung. Maka dari itu, perlunya sebuah kajian yang membahas tentang bagaimana bentuk bahasa rupa dari motif tenun Mbojo ini berkaitan dengan makna yang disampaikan oleh para penenun pada zaman dahulu agar bisa menjadi acuan yang valid. Dengan kata lain, simbol atau bahasa yang nantinya tidak dikaji akan mengalami kehilangan makna dan nilainya apabila tidak dipertahankan. Hal tersebutlah yang menyebabkan pergeseran makna dari motif yang digunakan.

\section{METODE PENELITIAN}

Metode yang digunakan dalam penelitian ini, yakni metode penelitian kualitatif yang di mana penulis melakukan observasi terhadap penenun lokal yang ada di Bima. Penenun- penenun tersebut memiliki rentang usia remaja hingga dewasa dan hanya dilakukan oleh wanita yang sudah siap berumah tangga. Kemudian dilanjutkan dengan studi literasi dari fenomena yang terkait, tentang kain songket, sejarah pengaruh budaya dan motif yang berlaku, hingga masuknya ajaran kepercayaan pada masingmasing budaya. Lalu diperkuat kembali dengan kegiatan wancara terkait fenomena dan objek yang diangkat selama penelitian oleh tokoh masyarakat dan ahli sejarawan lokal. Metode-metode tersebut dilakukan untuk menggali lebih dalam ilmu ataupun informasi yang dibutuhkan selama penelitian, tentang bagaimana pengrajin tenun menenun sebuah motif hingga mengenal makna motif tersebut lebih dalam.

\section{STUDI LITERATUR}

Aktivitas setiap masyarakat yang di wilayah yang berbeda dapat memengaruhi nilai budaya dan adat istiadatnya. Filosofi kehidupan tertuang dan tercermin dalam adat, serta terjalin dengan kepercayaan, unsur-unsur ragam hias pada kain merupakan salah satu bentuk ekspresi pengakuan terhadap keberadaan, keagungan dan kebesaran Tuhan [6]. Jadi dapat dikatakan bahwa tiap-tiap helai kain tersebut memiliki makna yang tersirat tentang arti kehidupan yang dalam. Indonesia yang merupakan 
wilayah dengan budaya yang berbeda-beda ini merupakan wilayah pembuat tenun dan adapula wilayah yang hanya menjadi penggunanya saja. Hal tersebut di pengaruhi oleh lingkungan budaya dan sumber alam yang ada pada beberapa wilayah.

Kain-kain nusantara ini memiliki peranan yang sangat penting bagi kegiatan dan aktifitas masyarakat sehari-hari. Selain berperan dalam aspek sosial budaya, kain-kain tersebut juga berperan sebagai sarana ekonomi dan komoditas perdagangan untuk di perjual belikan. Nusa Tenggara Barat memiliki dua daerah berupa Lombok dan Sumbawa di mana kedua daerah ini mempunyai latar belakang perkembangan masyarakat dan kebudayaan yang berbeda namun tetap memiliki persamaan. Kerajaan Bima khususnya yang merupakan pengaruh dari kekuasaan kerajaan Klungkung Bali dan kerajaan Goa Makasar sekitar abad 17. Ada ciri khas dari songket Sumbawa khususnya dari Bima antara lain gaya motif flora seperti bunga, daun, ranting dan dahan dengan nada kombinasi dengan flora terutama burung. Motif-motif itu dibentuk dengan lebih banyak menggunakan garis-garis kait di mana corak ini lebih menyerupai gaya kaligrafi. Walaupun cenderung menunjukkan bahwa desain itu lebih mendekati gaya desain dari Timur Tengah [6]. Motif yang diterapkan adalah motif pilin atau pilin berganda, motif tumpal dan motif tirai dan biasanya terdapat di sepanjang pinggiran selendang, ada pula motif ceplok bunga bersudut delapan yang tersebar dan motif seperti daun dengan sulur daunnya. Lalu, pada warna kain selendang lebih banyak variasinya dan lebih terikat pada warna yang gelap dan tradisional.

Bahasa adalah sebuah alat, instrument komunikasi yang digunakan untuk hidup bermasyarakat dalam menyampaikan pesan yang dimaksud. Bahasa memiliki betuk yang linear dan diakronik mengikuti aturan yang berlaku. Sedangkan rupa adalah istilah yang mengacu pada entitas atau realitas yang ada, dengan kata lain sesuatu yang berwujud dan bisa dilihat baik dari segi nilai estetikanya maupun bukan. Adanya perbedaan bahasa rupa barat dengan bahasa rupa tradisi, bisa dibedakan dari cara penggambarannya. Bahasa rupa barat yakni berupa penggambaran seperti animasi, komik ataupun gambar close-up yang ada di televisi, sedangakn bahasa rupa tradisional yakni gambar yang bisa dilihat pada candi yakni relief yang menggambarkan utuh dari ujung kepala hingga kaki [5].

Perbedaan tersebut bisa disebut dengan bahaa rupa barat atau modern dengan teknik penggambaran NPM (Natural Perspektif Momenopname) dan Bahasa Rupa Tradisional dengan teknik penggambaran RWD (Ruang Waktu Datar).

Bahasa rupa Primadi ini memiliki cara membacanya tersendiri, yakni cara wimba. Cara wimba ini memiliki dua tata ungkap yakni tata ungkap dalam dan tata ungkap luar. Tata ungkap dalam yakni suatu gambar tunggal yang menunjang suatu gambar atau artifak tersebut. Sedangkan tata ungkap luar adalah keseluruhan dari tata ungkap dalam, perspektif, lapisan, sudut pandang garis tanah dan sebagainya. Jadi dengan kata lain cara wimba itu sendiri adalah suatu cara menggambarkan tata ungkap suatu gambar atau artifak yang ada. Dalam bahasa rupa Primadi adapun istilah wimba, wimba adalah suatu objek gambar tunggal yang digambarkan secara berulang ataupun tidak dan mempunyai makna atau pesan yang terkandung [5]. Apabila wimba-wimba tersebut digambarkan seara berulang dan memiliki pola maka wimba tersebut kemungkinan memiliki pesan dan pola yang ingin disampaikan.

\section{HASIL ANALISA}

Penggambaran motif daerah Bima ini tidak lebih dari bunga dan tumbuh-tumbuhan. Tidak adanya gambar hewan dan manusia, menandakan kepercayaan yang dianut pada masa itu, melarang untuk menggambar makhluk hidup. Hal tersebut ditakutkan akan munculnya kembali ajaran agama lama. Motif-motif yang sering digunakan adalah sebagai berikut :

Penggambaran motif daerah Bima ini tidak lebih dari bunga dan tumbuh-tumbuhan. Tidak adanya gambar hewan dan manusia, menandakan kepercayaan yang dianut pada masa itu, melarang untuk menggambar makhluk hidup. Hal tersebut ditakutkan akan munculnya kembali ajaran agama lama. Motif-motif yang sering digunakan adalah sebagai berikut : 
1. Bunga Samobo

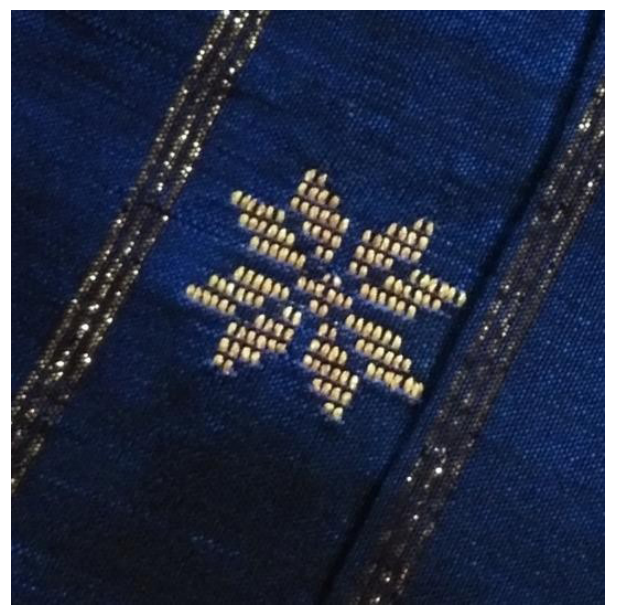

Gambar 1. Kain Motif Samobo

Samobo artinya sekuntum. Simbol yang bermakna sebuah pengharapan masyarakat, agar seseorang yang mengenakannya selalu berakhlak mulia.

\section{Bunga Satako}

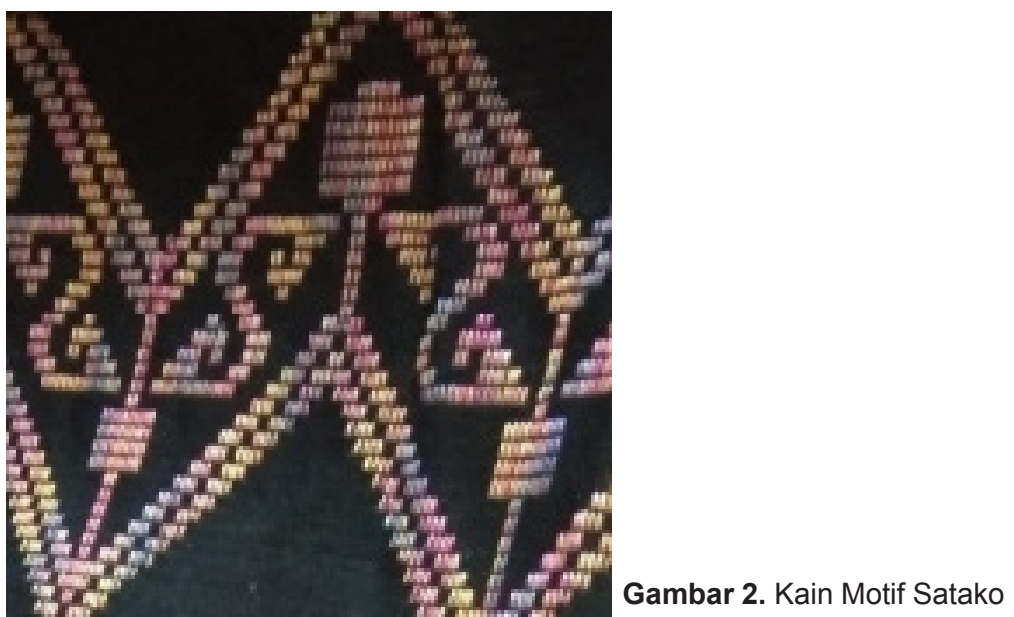

Samobo artinya sekuntum. Simbol yang bermakna sebuah pengharapan masyarakat, agar seseorang yang mengenakannya selalu berakhlak mulia.

3. Bunga Aruna

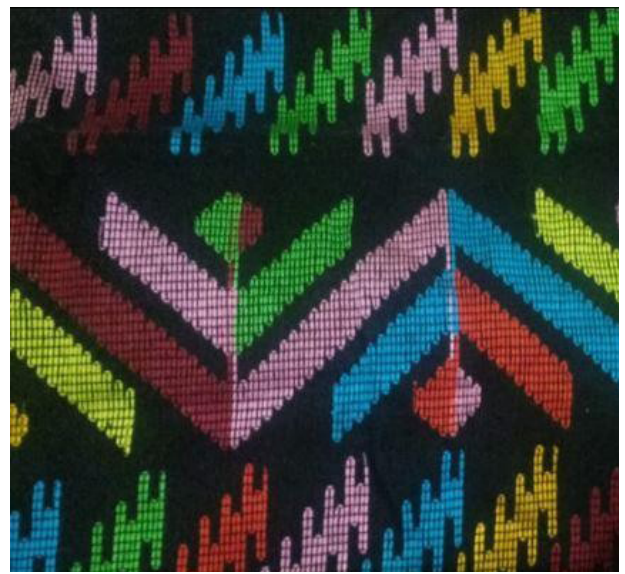

Gambar 3. Kain Motif Aruna

Bunga Aruna ini berarti bunga nanas yang di mana bunga nanas tersebut memiliki 99 helai atau sisik. Hal tersebut mengandung makna 99 sifat Allah, sebagai pencipta alam yang selalu dipuji dan disembah oleh hamba-Nya. 


\section{Kakando}

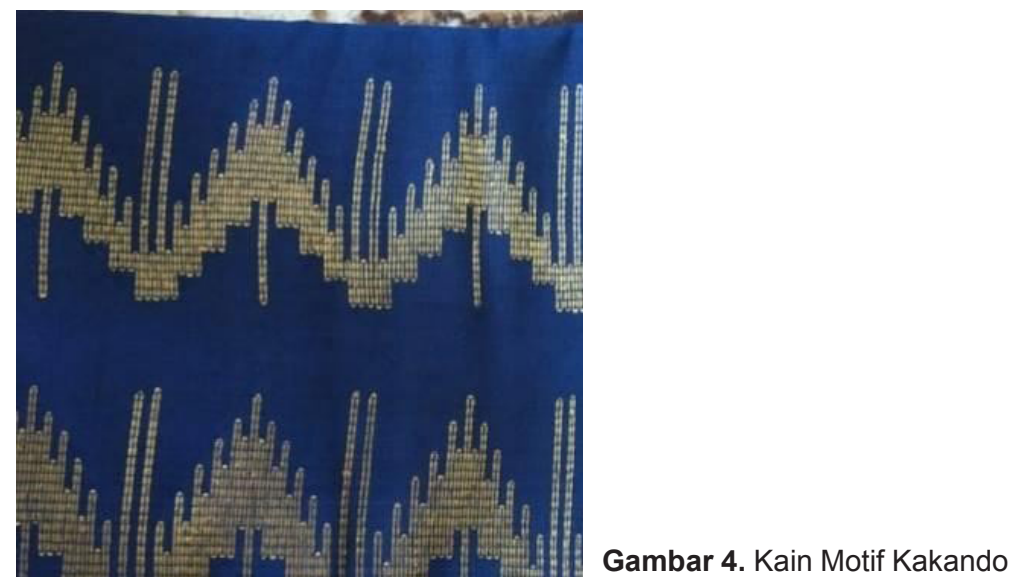

Arti kakando itu sendiri merupakan rebung, yang bermakna bagaimana masyarakat harus bersabar dan ulet setiap menjalani tantangan dalam kehidupan.

Tabel 1 Tabel analisis Motif Samobo
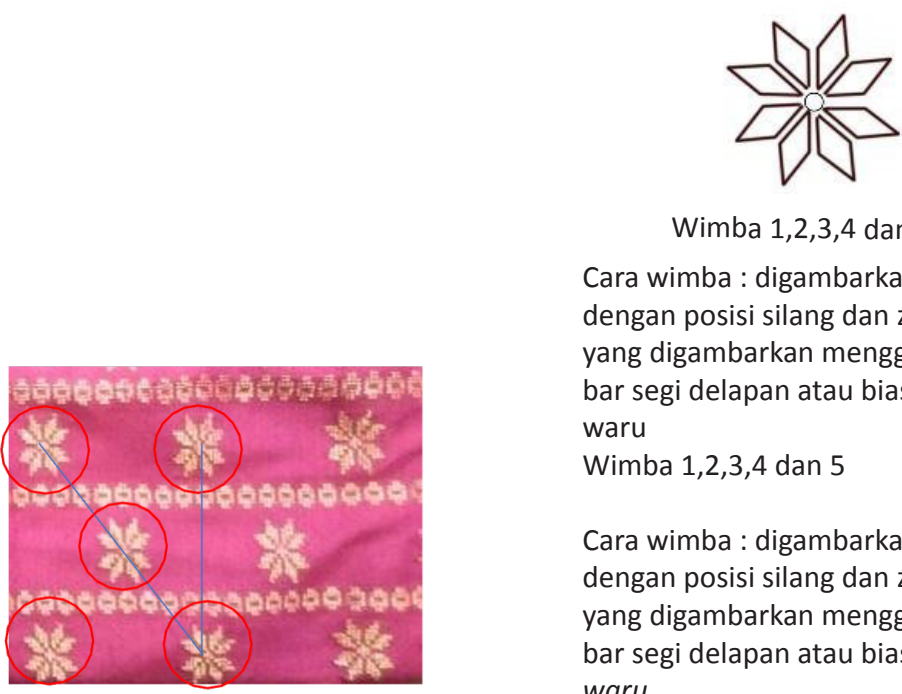

Wimba 1,2,3,4 dan 5

Cara wimba : digambarkan secara berulang dengan posisi silang dan zigzag. Motif bunga yang digambarkan menggunakan teknik gambar segi delapan atau biasa disebut Nggusu waru

Wimba 1,2,3,4 dan 5

Cara wimba : digambarkan secara berulang dengan posisi silang dan zigzag. Motif bunga yang digambarkan menggunakan teknik gambar segi delapan atau biasa disebut Nggusu waru

\section{Tata Ungkap Dalam 1}

Tata ungkap dalam yang ada pada motif tersebut, menciptakan ruang dari Bahasa rupa tradisi atau Ruang Waktu Datar. Kombinasi yang terbentuk dari motif tersebut membentuk pertemuan pada titik tengah yang mengacu pada pola budaya nusantara yang di mana memusatkan titik tersebut sebagai titik yang sakral. 


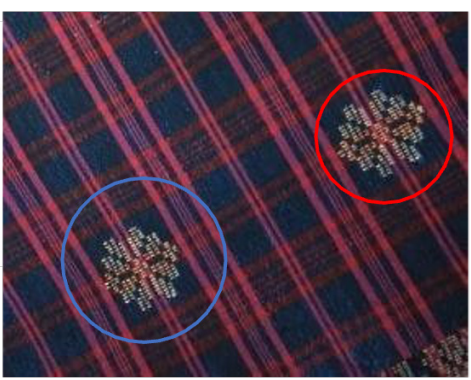

Cara wimba : digambarkan dengan menggunakan Motif Garis secara berulang membentang pada seluruh permukaan kain.

Wimba 2

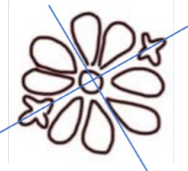

Cara wimba : digambarkan dengan menggunakan Motif Garis secara berulang membentang pada seluruh permukaan kain.

\section{Tata Ungkap Dalam}

Tata ungkap dalam yang digambarkan oleh kain tersebut yakni, penggambaran wimba 2 atau motif bunga ditenun secara sejajar dan lurus dengan motif bunga lainnya dan dipisahkan atau diberi jarak oleh wimba 1 atau motif garis. Komposisi ruang yang diciptakan menggunakan Bahasa rupa tradisi atau ruang waktu datar, karena penggambaran bunga dari tampak depan dan sinar $\mathrm{x}$ yang masuk menyinari seluruh permukaan motifnya.

\footnotetext{
HASIL ANALISA

Motif yang digunakan yakni bunga samobo yang berarti bunga sekuntum, yang di mana makna ini diharapkan dari pemakainya, agar senantiasa berakhlak mulia dan selalu berprilaku indah seperti semerbak sekuntum bunga.

Dimulai dari motif bunga samobo yang diberi lingakarn dan keterangan wimba lalu disusun sehingga membentuk satu tata ungkap dalam. Tata ungkap dalam, adalah susunan lengkap berbagai wimba beserta cara wimbanya yang ada pada suatu gambar [5]. Apabila ditarik garis atau dihubungkan struktur atau bentuk tersebut merupakan transformasi dari struktur alam berupa empat arah mata angin: Utara, Timur, Selatan, dan Barat dan satu titik pusat yang di mana menjadi titik pertemuan arah mata angin. Selain itu, motif yang digambarkan memiliki sudut ataupun titik pertemuan yang ada di tengah motif tersebut, yang melambangkan bentuk geometris yang digunakan oleh para penenun. Sudut lancip yang ada pada tiap bentuk, merupakan suatu isyarat bahwasanya kedudukan dan tempat paling tinggi tetap berada pada ketuhanan yang dipercayai oleh masyarakat setempat yakni Allah SWT [3].
}

Selain itu, motif bunga tersebut disusun dari delapan jajaran genjang dan membentuk sebuah objek bunga. Bentuk tersebut dalam bahasa Bima dikenal sebagai Nggusu Waru atau segi delapan yang di mana bentuk tersebut biasa digunakan pada atap rumah ataupun atap banteng. Selain itu digunakan sebagai persyaratan ideal bagi seseorang yang hendak memimpin sebagai Raja atau Sultan [3]

Beralih dari motif, kemudian bisa dilihat dari warna sarung ataupun kain tenun yang digunakan, dalam gambar tersebut warna dasar atau Dana yang digunakan adalah warna merah jambu ataupun hitam. Penggunaan warna tersebut bermakna atau memiliki simbol dari kesabaran dan ketabahan serta kemewahan dari orang yang mengenakan sarung tersebut [3] kain dengan perpaduan warna-warna seperti berikut tadi, mencerminkan sifat yang sabar, tabah dan kuat dalam menjalani kehidupan ataupun cobaan.

Adapula yang berbentuk bulat. Namun belum ada literatur yang menjelaskan bentuk motif bulat tersebut, apabila sebuah motif digambarkan tidak berurutan atau tidak memiliki pola maka pola tersebut sebenarnya tidak bisa dikatakan sebagai Wimba, dan hanya sebagai ornamen atau ragam hias penunjang motif lainnya[5]. 
Tabel 2 Tabel analisis Motif Salako

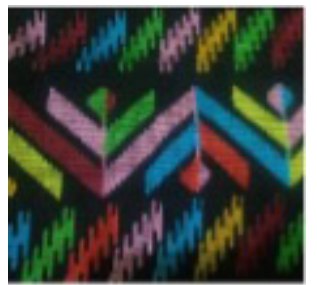

\section{Wimba 1}

Cara wimba : Wimba 1 merupakan representasi dari bunga nanas seperti makna yang telah dipaparkan.

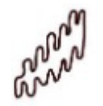

Wimba 2

Cara Wimba: Kemudian wimba 2 digambarkan dengan bentuk gelombang yang disebut Galomba Moti Toi

\section{HASIL ANALISA}

Bunga Aruna memiliki arti bunga nanas yang memiliki filosofi atau makna dari asma'ul husna atau nama-nama baik Allah SWT. Wimba 1 merupakan representasi dari bunga nanas dan wimba 2 merupakan representasi dari Gelombang laut atau disebut motif Gelomba Moti Toi. Motif Gelomba moti toi mengambil representasi dari laut yang di mana wilayah Bima ini dekat dengan lautan [7]. Selain itu juga salah satu mata pencaharian masyarakat Bima adalah nelayan, jadi makna gelomba moti toi ini juga sebagai sebagai bentuk rasa syukur karena laut merupakan sumber daya pangan masyarakat Bima.

Warna-warna yang digunakan untuk tiap motifnya memiliki warna yang berbeda. Warna-warna yang digunakan adalah warna-warna dasar yang sebelumnya sudah dipaparkan yakni warna merah (kala), kuning (monca), merah jambu (Bako), hijau (jao), biru (owa), dan hitam (me'e). Warna-warna tersebut memiliki makna satu kesatuan yang harmonis yakni kejayaan, keharmonisan, kebesaran, kemakmuran,perdamaian,kesabaran dan ketabahan [3].

Tabel 3 Tabel analisis Motif Aruna

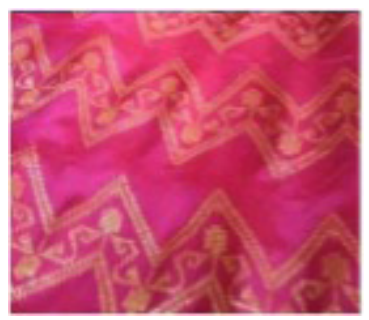

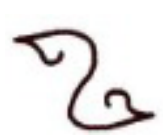

Wimba 1

Cara Wimba:

Wimba 1 dan 2 digambarkan dengan bentuk yang sama dengan posisi saling berhadapan dan saling mengelilingi wimba 3 .<smiles>c1ccccc1</smiles>

$$
\text { Wimba } 3
$$

Cara Wimba:

wimba 3 digambarkan secara tunggal pada tiap sudut atau ujung lekukan pada motif.

\section{Tata ungkapan dalam}

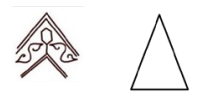

Tata ungkap dalam pada gambar ataupun kain tersebut. Bisa dilihat pada kombinasi wimba 1,2 dan 3 seperti pada gambar. Penggambaran tersebut digambarkan menggunakan bahasa rupa tradisi dan menciptakan ruang waktu datar sehingga terbentuk bentuk dasar segitiga. Cara komposisinya pun digambarkan menggunakan urutan motif dan penggambaran berulang- ulangnya bisa terlihat seperti upside down. 


\section{HASIL ANALISA}

Motif yang digambarkan pada kain merupakan representasi dari sekuntum bunga, sesuai dengan namanya yakni Bunga Satako yang artinya bunga sekuntum. Bisa terlihat dari wimba 1 dan 2, sulur bunga digambarkan secara zigzag dengan istilah Bimanya Kerai Cepe serta berhadapan dan menyambung dengan bunga lainnya. Kerai Cepe motif atau pola yang ditenun secara zigzag, dari bentuk zigzag tersebut bisa terlihat ada sudut yang menghadap ke atas ataupun ke bawah yang bermakna bahwa perjalanan manusia yang dinamis ada bahagia dan sedihnya. Kemudian Wimba 3 merupakan objek tunggal yang berada di titik puncak dan dikelilingi oleh wimba 1 dan 2 . Menandakan bahwa cara komposisi yang ada pada kain tersebut, menonjolkan wimba 3 sebagai pusat perhatian sehingga dalam penggambaran motif tersebut tercipta bentuk Segitiga atau Nggusu Tolu yang di mana sudut teratas merupakan sudut yang paling diutamakan.

Dalam kain tersebut, warna yang paling dominan yakni menggunakan warna Merah jambu atau Dana Bako [3] memiliki simbol bagi pengguna kain tersebut agar memiliki pribadi yang tabah dan tangguh dalam menjalani hidup dan mengemban tugas. Sedangkan warna motif yang ditenun yakni menggunakan benang emas, jika dahulu benang emas hanya digunakan oleh bangsawan dan kerajaan sekarang benang emas sudah bisa digunakan secara meluas tergantung dengan permintaan pasar tanpa memandang kelas sosial.

Tabel 4 Tabel analisis Motif Kakando

NO GAMBAR

BAHASA RUPA

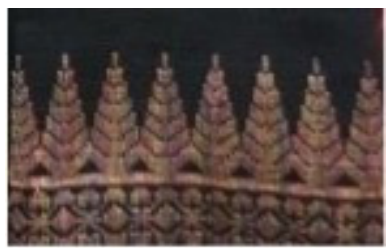

Wimba 1 ini merupakan representasi dari bentuk rebung, maka digambarkan menyerupai bentuk segitiga yang berjejer dalam istilah Bima nya yakni Cori Paluda.

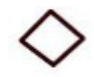

Wimba 2

Wimba 2 digambarkan dengan bentuk geometri jajaran genjang, atau disebut Pado Waji dan digambarkan secara berulang dengan ukuran yang lebih kecil.
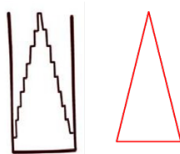

Wimba 1

Wimba 1 digambarkan berbentuk segitiga yang merupakan representasi dari rebung bambu itu sendiri.

Tata ungkap dalam :

Motif-motif kakando pada kain berikut digambarkan secara berulang dengan penggunaan warna yang berbeda.

\section{HASIL ANALISA}

Sama halnya dengan motif bunga kakando sebelumnya. Bunga kakando adalah bunga rebung yang merupakan motif tenun masyarakat Bima, yang ditenun menyerupai bentuk segitiga atau Nggosu Tolu. Nggusu tolu sendiri bermakna bentuk yang memiliki sudut lancip, pada bagian sudut lancip tersebut memiliki isyarat bahwa kedudukan tertinggi dan teratas yakni Tuhan Semesta Alam [3]. Penggambaran motif bunga kakando digambarkan berbentuk segitiga berjejer atau disebut Cori Paluda. Penggambaran motif bunga kakando yang memiliki bentuk segitiga dan digambar secara berjejer disebut juga Cori Paluda bermakna hubungan yang harmonis antara pemimpin dan masyarakat.

Penggunaan warna yang paling dominan yakni warna hitam atau disebut Dana Me'e. Penggunaan warna hitam biasanya ditenun oleh masyarakat Dou Donggo yang di mana menurut Dou Donggo sendiri warna hitam adalah warna sakral, memaparkan bahwa penggunaan warna hitam oleh masyarakat Dou Donggo dilakukan sebagai bentuk penghormatan terhadap lingkungan alam yang telah mewarisi sumber kehidupan dan kesejahteraan. 


\section{KESIMPULAN}

Menurut hasil penelitian dan pendalaman bahasa rupa yang dilakukan, maka dapat disimpulkan Bahasa rupa dari motif tenun Bima digambarkan menggunakan Bahasa Rupa Tradisi atau Ruang Waktu Datar. Motif-motif ditenun secara apa adanya tanpa adanya objek yang menumpuk. Bahasa Rupa Tradisi ini merupakan bahasa rupa yang mengacu pada aspek bercerita pada sebuah gambar yang digambar secara utuh. Motif tenun yang sudah dijabarkan diatas, memiliki cara wimba dan tata ungkap dalam tersendiri. Analisis bahasa rupa pada motif-motif tersebut, membuat gambar atau visual yang terkandung menjadi bermakna, baik dari warna, motif dan bentuk serta perbedaan gaya gambar atau bentuknya. Secara tidak langsung, walaupun motif-motif yang ditenun tanpa adanya filososfi dasar atau ketentuan dasar yang masyarakat ketahui, kain tenun tersebut tetap memiliki nilai estetik tersendiri.

Dari masalah yang sudah dijabarkan sebelumnya, maka dari kesimpulan ini menjelaskan, bahwa pentingnya ilmu dan pengetahuan tentang makna motif dari penenun terdahulu sebagai pedoman dalam hidup ataupun warisan budaya yang harus dilestarikan. Apabila dikaitkan dengan acuan teori yang ada, masing-masing motif memiliki makna keselarasan dalam hidup, dan penghormatan serta rasa syukur kepada Allah SWT sebagai Tuhan yang diyakini oleh masyarakat sekitarnya.

Bima adalah salah satu daerah dengan penghasil kain tenun tradisional yang diwariskan secara turun temurun, kain tersebut dinamakan kain Mbojo. menenun sudah menjadi kewajiban agar masyarakat tetap bisa berpenghasilan, namun para penenun lupa untuk mewariskan ilmu pengetahuan tentang makna motif yang ditenun, maka dari itu dilakukan penelitian ini agar ilmu tentang kain tenun nusantara khususnya kain tenun Bima bisa lebih dikenal dan dijadikan pedoman bagi penelitian selanjutnya.

Informasi tentang makna motif pastinya akan sangat membantu membangkitkankembali ilmu dasar tentang menenun, yang sebelumnya tidak tersampaikan oleh para penenun terdahulu. Sebagai contoh ketika nantinya sektor pariwisata meningkat dan kampun tenun men Jadi salah satu destinasi yang diminati maka ilmu dasar menenun tersebut setidaknya harus mulai dipelajari agar nantinya wisatawan luar ataupun dalam negeri bisa mengenal kain Mbojo ini sebagai kain yang penuh makna dan filosofi.

\section{PERNYATAAN PENGHARGAAN}

Penulis mengucapkan terimakasih kepada pembimbing Tesis Magister Desain FSRD ITB Dr. Yan yan Sunarya S.Sn.,M.Sn. yang telah membantu dan mengarahkan dalam proses penyusunan penelitian ini. Serta ucapan terimakasih kepada narasumber Alan Malingi dan Nurhayati yang sudah memberikan kesempatan dan waktu untuk berdiskusi bersama tentang fenomena yang diangkat.

\section{DAFTAR PUSTAKA}

[1]. Putra, A. (2019). Keindahan Kain Tenun Mbojo, Cermin Budaya Khas Bima. Retrieved 18 March 2020 from Internet : https://travel.kompas.com/read/2015/06/14/111600727/Keindahan.Kain. Tenun.Mbojo.Cermin.Budaya.Khas.Bima

[2]. Malingi,A.(2016). Romantika Bima. online at https://alanmalingi.wordpress.com/2016/12/02/ menenun-bagi-perempuan-bima/ accessed 29 April 2021

[3]. Ismail, M. and Malingi, A., 2010. Ragam Motif Tenun Bima Dompu. 1st ed. Mataram: Mahani Persada.

[4]. Mubin, IImiawan. (2016). Makna Simbol atau Motif Kain Tenun khas masyarakat daerah Bima di kelurahan Raba Dompu Kota Bima Propinsi Nusa Tenggara Barat, journal.ummat.ac.id/index.php/ historis/article/download/205/173 untuk artikel jurnal motif tenun khas Bima (diakses tanggal 29 mei 2018 pukul 10.33

[5]. Tabrani, Primadi. (2005). Bahasa Rupa. Bandung: Penerbit Kelir.

[6]. Kartiwa, Suwati. (1996). Kain Songket Indonesia. Jakarta: Djambatan.

[7]. Wawancara Sejarawan Bima, Ruslan Muhammad atau Alan Malingi. Di rumahnya Jl. Sadia Kota Bima pada hari Selasa 23 Juli 2019 pukul 16.27 WITA hingga selesai. Dan hari Selasa 3 November 2020 pukul 11.57 WITA hingga selesai 